\title{
Helse og dødelighet - to sider av samme sak?
}

Helse er det viktigste vi har, men samtidig er helsebegrepet vanskelig og omdiskutert (1). Helsebegrepet har fysiske, psykiske og sosiale aspekter og vi snakker om et holistisk, bio-psyko-sosialt helsebegrep. WHO definerer helse som «en tilstand av komplett fysisk, mental og sosial velvære». De fleste er enige om at helse er mer enn fravær av sykdom.

I mange år har befolkningsbaserte helseundersøkelser hatt høy prioritet for politikere og forskere. Arbeidet med å utvikle gode målemetoder for helse har stått sentralt, sammen med kartlegging av spesifikke sykdomstilstander og risikofaktorer (2). Helseundersøkelsene i Nord-Trøndelag (HUNT) er blant de viktigste helseundersøkelsene også internasjonalt og har skaffet mye kunnskap som kan brukes for å bedre folkehelsen. Samtidig har også HUNT sine begrensninger (3).

Selvrapportert helse, på norsk også kalt selvopplevd eller egenvurdert helse, er en genial og enkel metode for å kartlegge helse ved hjelp av ett spørsmål: Hvordan vil du karakterisere din egen helse for tiden? Ofte brukes fire svaralternativer, svært god, god, ikke helt god og dårlig. Selvrapportert helse er kalt en intuitiv eller spontan helsevurdering, respondentene kan tenkes å svare raskt og ulike alternativer veies opp mot hverandre. Samtidig er det holdepunkter for at metoden avspeiler en gjennomgripende, men også dynamisk selvoppfatning (4). I en rekke studier også i Norge (5) har man undersøkt hvorfor ulike svaralternativer velges (6) og hvilke aspekter ved individets helse og livssituasjon som er assosiert med hva man svarer (7).

Dødelighet er et annet sentralt begrep innen epidemiologi og helseforskning. Dette er enklere å tallfeste og forholde seg til enn helse. Man sammenlikner levetiden til ulike individer og grupper. Forventet levealder brukes ofte som et mål på folkehelsen (1).

Umiddelbart vil man tenke at dødelighet bare er forbundet med objektive eller sykdomsrelaterte helseaspekter. Men slik ser det ikke ut til å være. En lang rekke studier har vist at det enkle helsemålet selvrapportert helse predikerer dødelighet, også etter justering for kjente fysiske helseproblemer (8-9). Helseaspekter som ikke er knyttet til dødelige sykdommer, men som springer ut av daglige plager og funksjonsproblemer er mer avgjørende for den selvrapporterte helsen og predikerer også dødelighet sterkere enn f.eks. legediagnostiserte sykdommer $(7,9)$. Sammenhengen mellom selvrapportert helse og dødelighet er komplisert. For eksempel kan personer som karakteriserer helsen sin som god, ha en mer helsebringende og mindre risikofylt atferd (9), noe som igjen kan forklare overdødelighet av ulykker i gruppen som rapporterer mindre god helse.

I løpet av det siste tiåret er sosiale ulikheter i helse og dødelighet kommet på agendaen i Norge. Studier har vist at de nordiske land, til tross for sitt sosialdemokratiske styresett, har like store forskjeller i selvrapportert helse og i dødelighet som andre vest-europeiske land, også kalt det nordiske helseparadoks (10).

En gruppe forskere ved Norges teknisk-naturvitenskapelige universitet (NTNU) og HUNT har stilt spørsmål ved om det er metodefeil i forskningen som myndighetene baserer seg på når de lager handlingsplaner mot sosiale helseulikheter (11). Feilrapporterer de svakere stilte helsetilstanden sin, mens akademikere angir sin selvrapporterte helse mer «korrekt» grunnet bedre kunnskaper om helse? Gruppen har tidligere publisert en studie der ulike utdanningsgrupper sammenliknes (12), mens dette nummer av Tidsskriftet har en artikkel der Holseter og medarbeidere har undersøkt mulige forskjeller mellom yrkesklasser og inntektsgrupper (13). Liknende studier er tidligere gjort i Sverige, USA, Nederland og Frankrike (14).

Forfatterne bruker dødelighet som gullstandard og undersøker «troverdigheten» i studier basert på selvrapportert helse. De finner, som $i$ andre land, at sammenhengen mellom selvrapportert helse og dødelighet er nokså lik mellom sosiale klasser. Et viktig funn er at arbeidsledige med dårlig selvrapportert helse hadde enda høyere dødelighet enn forventet, sammenliknet med andre grupper - aller høyest for menn. Forfatterne antyder at denne overdødeligheten ikke er relatert til helse, men det er vel rettere å si at den ikke er relatert til påvist sykdom. Forfatterne bruker begrepet reell eller faktisk helse, eller objektiv helse. De synes da å mene mengden av sykdommer eller risikofaktorer. Jeg tror vi skal holde fast på at helse er noe mer og ikke bare biologi (14).

Helse og dødelighet er to ulike fenomener, som riktignok samvarierer i stor grad. Det dreier seg om et langt liv og et godt liv, om å legge år til livet og liv til årene. Begge deler er viktig i folkehelsearbeidet og i arbeidet med å utjevne de sosiale helseulikhetene i Norge, som NTNU-forskerne på en viktig måte setter søkelyset på i de aktuelle studiene.

\section{Sturla Gjesdal \\ sturla.gjesdal@isf.uib.no}

Sturla Gjesdal (f. 1952) er dr.med., professor i allmennmedisin og leder av forskningsgruppen i sosialepidemiologi ved Institutt for global helse og samfunnsmedisin, Universitetet i Bergen.

Forfatter har fylt ut ICMJE-skjemaet og oppgir ingen interessekonflikter.

Litteratur

1. Mæland JG. Hva er helse? Oslo: Universitetsforlaget, 2009

2. McDowell I. Measuring health: a guide to rating scales and questionnaires 3. utg. New York, NY: Oxford University Press, 2006.

3. Langhammer A, Krokstad S, Romundstad P et al. The HUNT study: participation is associated with survival and depends on socioeconomic status, diseases and symptoms. BMC Med Res Methodol 2012; 12: 143.

4. Bailis DS, Segall A, Chipperfield JG. Two views of self-rated general health status. Soc Sci Med 2003; 56: 203-17.

5. Fylkesnes K, Førde OH. The Troms $\varnothing$ Study: predictors of self-evaluated health has society adopted the expanded health concept? Soc Sci Med 1991: 32: 141-6.

6. Manderbacka K. Examining what self-rated health question is understood to mean by respondents. Scand J Soc Med 1998; 26: 145-53.

7. Mavaddat N, Kinmonth AL, Sanderson S et al. What determines Self-Rated Health (SRH)? A cross-sectional study of SF-36 health domains in the EPICNorfolk cohort. J Epidemiol Community Health 2011; 65: 800-6.

8. DeSalvo KB, Bloser N, Reynolds K et al. Mortality prediction with a single general self-rated health question. A meta-analysis. J Gen Intern Med 2006; 21: 267-75.

9. Benyamini Y. Why does self-rated health predict mortality? An update on current knowledge and a research agenda for psychologists. Psychol Health 2011; 26 : 1407-13.

10. Mackenbach JP. The persistence of health inequalities in modern welfare states: the explanation of a paradox. Soc Sci Med 2012; 75: 761-9.

11. St.meld. nr. 20 (2006-2007). Nasjonal strategi for å utjevne sosiale helseforskjeller. www.regjeringen.no/nb/dokumenter/Stmeld-nr-20-2006-2007-/ id449531/ (17.2.2015).

12. Dalen JD, Huijts T, Krokstad S et al. Are there educational differences in the association between self-rated health and mortality in Norway? The HUNT Study Scand J Public Health 2012: 40:641-7.

13. Holseter C, Dalen JD, Krokstad S et al. Selvrapportert helse og dødelighet i ulike yrkesklasser og inntektsgrupper i Nord-Trøndelag. Tidsskr Nor Legeforen 2015; 135: $434-8$

14. Quesnel-Vallée A. Self-rated health: caught in the crossfire of the quest for true' health? Int J Epidemiol 2007; 36: 1161-4. 